\title{
The Influence of Organizational Culture and Work Environment on the Performance of Naval Command and Staff Collage (Seskoal) with Job Satisfication
}

\author{
Zukarnaen $^{1 *}$, Dedi Purwana, Ari Saptono \\ 1 Universitas Negeri Jakarta, Indonesia
}

Corresponding Author: Zukarnaen, zuklarain23@gmail.com

$$
\text { ABSTRACT }
$$

Staff performance is very crucial in the sustainability of the company. Some factors that are thought to strongly influence performance are organizational culture, work environment, and job satisfaction. Thus, the study aimed to analyze the strong influence of organizational culture and work environment on job satisfaction, then to analyze the strong influence of organizational culture and work environment on performance, then

ARTICLE INFO

Article history:

Received

June 23, 2020

Revised

July 10, 2020

Accepted

July 20, 2020

How to cite

Journal Homepage Published by analyze the effect of job satisfaction on performance, finally to find out and analyze the indirect effect of organizational culture and work environment towards the performance of Seskoal soldiers through job satisfaction. This research uses quantitative methods with data obtained through questionnaires with Likert scale assessment. With a total of 137 Seskoal soldiers. The analysis results show that organizational culture and work environment with job satisfaction are positively and significantly related, organizational culture and work environment with performance are positively and significantly related, job satisfaction with performance is positively and significantly related, there is a relationship between the influence of organizational culture and performance with mediated by job satisfaction and there is a relationship between the influence of the work environment with performance mediated by job satisfaction.

Keywords: Organizational Culture, Work Environment, Job Satisfaction

Zukarnaen, Z, Purwana, D., \& Saptono, A. (2020). The Influence of Organizational Culture and Work Environment on the Performance of Naval Command and Staff College with Job Satisficatoin. IJoASER (International Journal on Advanced Science, Education, and Religion), 3(2). 34-45.

https://doi.org/10.33648/ijoaser.v3i2.55

https:/ / ojs.staialfurqan.ac.id/IJoASER/

STAI Al-Furqan Makassar

\section{INTRODUCTION}

Staff performance is very crucial in the sustainability of the company. That's why, staff performance must be considered so that the company can continue to run by its objectives (Chaudhry, 2017; Pitaloka \& Sofia, 2014; Che et al, 2019). Naval Command and Staff Collage (Seskoal) are Educational Institutions that have functions such as reviewing issues of defense and security at sea at strategic levels, operations, and maritime assessments and have the functions of formulating, preparing plans and preparing educational plans and programs that include finance, logistics, and management of education system development and evaluation. So it can be said that the quality of Education in Seskoal is determined by the readiness of staff involved in the Education Process. As the heart of the quality of education and the formation of the soldier's character, it takes great attention to the performance of Seskoal staff. 
Performance was influenced by several factors in the company (Belias, 2015: Colquitt, 2013; Naibaho et al., 2015). Based on literature studies and research surveys conducted, obtained several factors that are suspected to strongly influence performance staff namely organizational culture (OC), work environment (WE) and job satisfaction (JS) (Indrasari, 2017; Jayaweera, 2015; Asiedu, 2015).

In line with the opinions of experts, where according to Syahrum et al., (2016), Hardiyono (2017) \& Khuzaeni et al., (2013) stated that organizational culture can influence the results of employee performance. Therefore the organization must form a culture that is suitable for its employees. This culture will indirectly regulate all activities and habits in the organization (Alizadeh et al., 2012; Hanafi \& Yohana, 2017; Steven, 2016). In addition to organizational culture, companies also need to pay attention to the work environment. Jayaweera (2015) \& Salunke (2015) reported that the work environment will affect job satisfaction so that it directly affects employee performance. In his research Pawirosumarto (2017) revealed that job satisfaction can mediate the influence of organizational culture and work environment on performance so that the impact caused becomes greater.

While, this research was more complex than those previous research who studied three aspect namely organizational culture (OC), work environment (WE) and job satisfaction (JS). The researcher aimed to analyze the strong influence of organizational culture (OC) and work environment (WE) on the job satisfaction (JS) of the Seskoal soldiers, then analyze the influence of the OC and WE on the performance of the Seskoal soldiers, then to analyze the strength of the influence of the JS on the Perormace of the Seskoal soldiers, finally to find out and analyze the OC and WE on the Performance fo Seskoal soldiers through JS.

\section{METHODS}

This research uses quantitative methods. Aims to test the effect of a variable on other variables to explain the relationship and influence between variables. Next, the data were analyzed using the partial least square (PLS) technique using smartpls version 3.9 to test the hypothesis. In detail, the researchers aimed to find out the relationship and the effect of OC and WE on Pf with JS as an intervening variable. Samples taken were from the Navy personnel serving in Seskoal.

The population taken is the total of Seskoal Soldiers totaling 210 people, Seskoal Soldiers consisting of 118 Bintara people, and 92 Private Officers. With samples taken using the Yamene / Slovin formula in (Sugiono, 2018) which has the formula:

$$
n=\frac{N}{1+N\left(e^{2}\right)}
$$

Explanation:

$\mathrm{n}=$ Amount Sample

$\mathrm{N}=$ Amount Population

e $=$ Sample error rate (margin error) $5 \%$

Thus, the number of samples that must be taken:

$$
\begin{aligned}
n & =\frac{210}{1+210(0,0025)} \\
& =137 \text { Responden }
\end{aligned}
$$




\section{RESULT AND DISCUSSION}

Characteristics of respondents sorted by gender, age, education level, and service age of the respondents are described as follows:

Figure 1. Respondents based on Gender

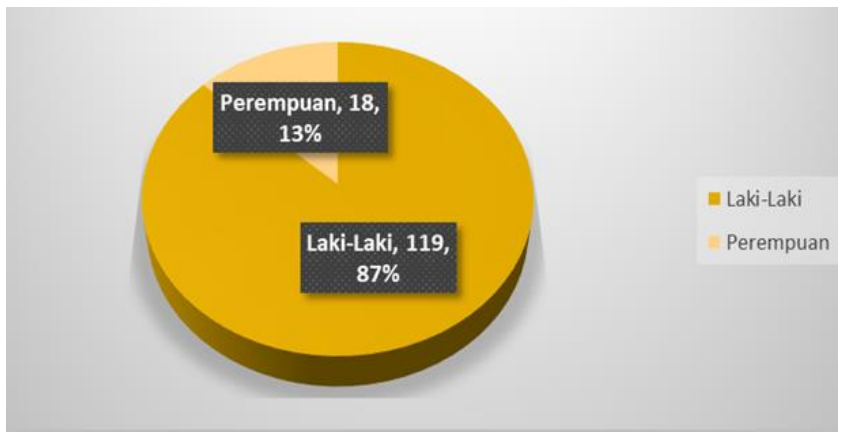

Figure 2. Respondents by Age

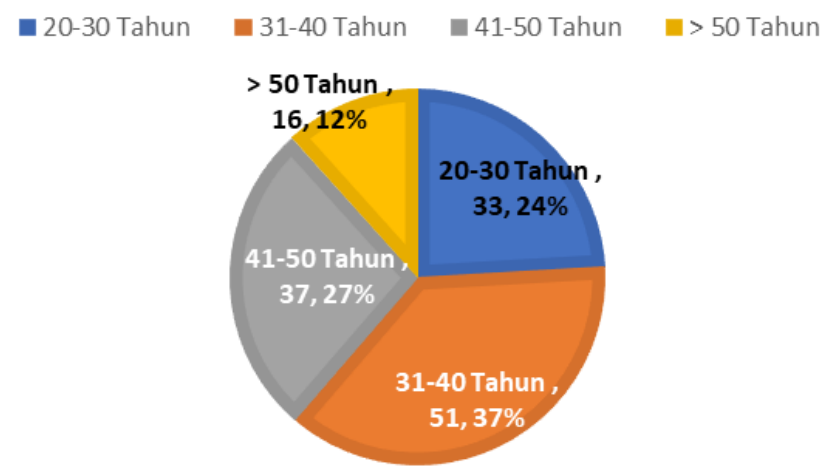

Figure 3. Respondents by Service Age

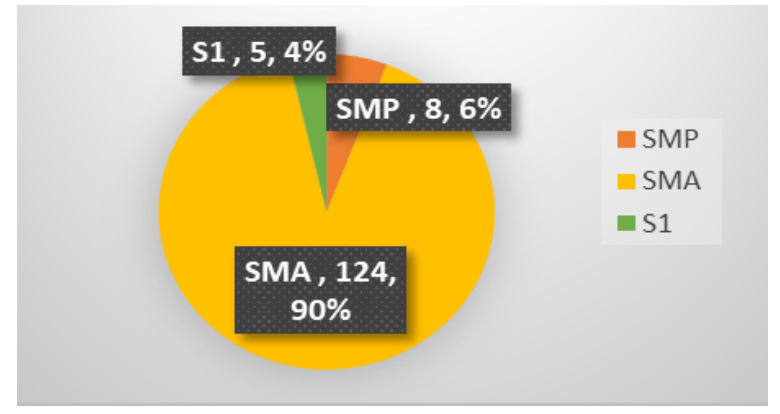

\section{Instrument Validity and Reliability Test Results}

The research questionnaire was distributed to 137 respondents who were all Seskoal soldiers serving in the Seskoal Educational Institute on Jl. Ciledug Ray Kebayoran Lama Cipulir South Jakarta. The questionnaire was first tested with 30 
respondents. The validity test used is corrected item-total correlation is processed by the SPSS program. The reliability test will use Cronbach's Alpha reliability test.

Because the trial sample in this study is 30 , the value of the $\mathrm{R}$ table to be compared with the calculated R-value of each question item should be 0.361 , then the question is valid if $r$ count $>0.361$. Table 1 is the result of the test:

Table 1. Instrument Validity Test Results

\begin{tabular}{|c|c|c|c|c|}
\hline Variable & Indicator & R Count & R Table & Validity \\
\hline \multirow{10}{*}{ Work Environment } & WE1 & 0,851 & 0,361 & $\checkmark$ \\
\hline & WE2 & 0,918 & 0,361 & $\checkmark$ \\
\hline & WE3 & 0,929 & 0,361 & $\checkmark$ \\
\hline & WE4 & 0,903 & 0,361 & $\checkmark$ \\
\hline & WE5 & 0,893 & 0,361 & $\checkmark$ \\
\hline & WE6 & 0,861 & 0,361 & $\checkmark$ \\
\hline & WE7 & 0,931 & 0,361 & $\checkmark$ \\
\hline & WE8 & 0,930 & 0,361 & $\checkmark$ \\
\hline & WE9 & 0,931 & 0,361 & $\checkmark$ \\
\hline & WE10 & 0,898 & 0,361 & $\checkmark$ \\
\hline \multirow{14}{*}{ Organizational Culture } & OC1 & 0,914 & 0,361 & $\checkmark$ \\
\hline & OC2 & 0,855 & 0,361 & $\checkmark$ \\
\hline & OC3 & 0,901 & 0,361 & $\bar{\checkmark}$ \\
\hline & OC4 & 0,889 & 0,361 & $\checkmark$ \\
\hline & OC5 & 0,881 & 0,361 & $\checkmark$ \\
\hline & OC6 & 0,831 & 0,361 & $\checkmark$ \\
\hline & OC7 & 0,908 & 0,361 & $\checkmark$ \\
\hline & OC8 & 0,892 & 0,361 & $\checkmark$ \\
\hline & OC9 & 0,858 & 0,361 & $\checkmark$ \\
\hline & OC10 & 0,900 & 0,361 & $\checkmark$ \\
\hline & OC11 & 0,823 & 0,361 & $\checkmark$ \\
\hline & OC12 & 0,899 & 0,361 & $\checkmark$ \\
\hline & OC13 & 0,933 & 0,361 & $\checkmark$ \\
\hline & OC14 & 0,825 & 0,361 & $\checkmark$ \\
\hline \multirow{7}{*}{ Job Satisfaction } & JS1 & 0,853 & 0,361 & $\checkmark$ \\
\hline & IS2 & 0,834 & 0,361 & $\checkmark$ \\
\hline & JS3 & 0,871 & 0,361 & $\checkmark$ \\
\hline & JS4 & 0,832 & 0,361 & $\checkmark$ \\
\hline & JS5 & 0,872 & 0,361 & $\checkmark$ \\
\hline & JS6 & 0,878 & 0,361 & $\checkmark$ \\
\hline & JS7 & 0,866 & 0,361 & $\checkmark$ \\
\hline
\end{tabular}




\begin{tabular}{|l|c|c|c|c|}
\hline \multirow{5}{*}{} & JS8 & 0,881 & 0,361 & $\checkmark$ \\
\cline { 2 - 5 } & JS9 & 0,900 & 0,361 & $\checkmark$ \\
\cline { 2 - 5 } & JS10 & 0,921 & 0,361 & $\checkmark$ \\
\hline \multirow{5}{*}{ Performance } & Pf1 & 0,888 & 0,361 & $\checkmark$ \\
\cline { 2 - 5 } & Pf2 & 0,775 & 0,361 & $\checkmark$ \\
\cline { 2 - 5 } & Pf3 & 0,864 & 0,361 & $\checkmark$ \\
\cline { 2 - 5 } & Pf4 & 0,814 & 0,361 & $\checkmark$ \\
\cline { 2 - 5 } & KK5 & 0,893 & 0,361 & $\checkmark$ \\
\cline { 2 - 5 } & Pf6 & 0,789 & 0,361 & $\checkmark$ \\
\cline { 2 - 5 } & Pf7 & 0,775 & 0,361 & $\checkmark$ \\
\cline { 2 - 5 } & Pf8 & 0,847 & 0,361 & $\checkmark$ \\
\cline { 2 - 5 } & Pf9 & 0,867 & 0,361 & $\checkmark$ \\
\cline { 2 - 5 } & Pf10 & 0,870 & 0,361 & $\checkmark$ \\
\hline
\end{tabular}

Based on the analysis results in Table 1 , all question items have an $\mathrm{R}$ count $>0.361$ so that it is declared valid. Then the instrument reliability test was conducted. In this test, the instrument is said to be reliable if cronbachs alpha> 0.7 .

Table 2.

The Reliability Test Result

\begin{tabular}{|c|c|c|c|}
\hline Variable & $\begin{array}{c}\text { Cronbachs } \\
\text { Alpha }\end{array}$ & $\begin{array}{l}\text { Cut } \\
\text { Value }\end{array}$ & Reability \\
\hline Work Environment (WE) & 0,980 & 0,7 & $\checkmark$ \\
\hline $\begin{array}{l}\text { Organizational Culture } \\
\text { (OC) }\end{array}$ & 0,981 & 0,7 & $\checkmark$ \\
\hline Job Satisfaction (JS) & 0,972 & 0,7 & $\checkmark$ \\
\hline Performance (Pf) & 0,964 & 0,7 & $\checkmark$ \\
\hline
\end{tabular}

From Table 2 it is known that the Cronbachs alpha value of all instruments has $>$ 0.7 , indicating that all instruments are quite reliable in measuring the research variables.

\section{PLS analysis}

Analysis using the Partial Least Square (PLS) technique is performed to illustrate the estimation results model which can then be used as a reference in conducting hypothesis testing. PLS analysis will begin with the outer model testing phase, testing the goodness of fit model and testing the inner model as follows.

\section{Testing the Outer Model}

Outer models include testing Convergent Validity, Discriminant Validity and Composite reliability. The indicator is declared valid if the loading factor value> 0.7, AVE> $0.5,>\mathrm{r}$ (where $\mathrm{r}=$ correlation coefficient construct with other latent constructs) and the construct is declared reliable if cronbachs alpha> 0.7 and composit reliability> 0.7 . 
Table 3. Results of Outer Model Testing

\begin{tabular}{|c|c|c|c|c|c|c|}
\hline \multirow[t]{2}{*}{ Variable } & \multirow[t]{2}{*}{$\begin{array}{c}\text { Indicato } \\
\mathbf{r}\end{array}$} & \multicolumn{2}{|c|}{$\begin{array}{l}\text { Convergent } \\
\text { Validity }\end{array}$} & \multirow[t]{2}{*}{$\begin{array}{l}\text { Descriminant } \\
\text { Validity }\end{array}$} & \multicolumn{2}{|c|}{ Reliability } \\
\hline & & $\begin{array}{l}\text { Loadin } \\
\text { g Factor }\end{array}$ & $\begin{array}{c}\text { AV } \\
\text { E }\end{array}$ & & $\begin{array}{c}\text { Cronbach } \\
\text { s Alpha }\end{array}$ & $\begin{array}{c}\text { Composit } \\
\text { e } \\
\text { Reliabilit } \\
y\end{array}$ \\
\hline \multirow{14}{*}{$\begin{array}{l}\text { Organization } \\
\text { al Culture }\end{array}$} & OC1 & 0,911 & \multirow{14}{*}{$\begin{array}{l}0,79 \\
1\end{array}$} & \multirow{14}{*}{$\begin{array}{l}\sqrt{A V E}=\mathbf{0 , 8 8 9} \\
\text { Correlation } \\
\text { Coefficient }(\mathrm{r}) \text { : } \\
0,810 ; 0,744 ; \\
0,755\end{array}$} & \multirow[t]{14}{*}{0,980} & \multirow[t]{14}{*}{0,981} \\
\hline & OC10 & 0,893 & & & & \\
\hline & OC11 & 0,850 & & & & \\
\hline & OC12 & 0,909 & & & & \\
\hline & OC13 & 0,932 & & & & \\
\hline & OC14 & 0,843 & & & & \\
\hline & OC2 & 0,865 & & & & \\
\hline & OC3 & 0,904 & & & & \\
\hline & OC4 & 0,891 & & & & \\
\hline & OC5 & 0,907 & & & & \\
\hline & OC6 & 0,846 & & & & \\
\hline & OC7 & 0,913 & & & & \\
\hline & OC8 & 0,902 & & & & \\
\hline & OC9 & 0,881 & & & & \\
\hline \multirow[t]{10}{*}{ Performance } & Pf1 & 0,872 & \multirow{10}{*}{$\begin{array}{l}0,77 \\
2\end{array}$} & \multirow{10}{*}{$\begin{array}{l}\sqrt{\boldsymbol{A V E}}=\mathbf{0 , 8 7 9} \\
\text { Correlation } \\
\text { Coefficient }(\mathrm{r}): \\
0,878 ; 0,705 ; \\
0,810 \\
\sqrt{\boldsymbol{A V E}}>\mathbf{r}\end{array}$} & \multirow[t]{10}{*}{0,967} & \multirow[t]{10}{*}{0,971} \\
\hline & Pf10 & 0,902 & & & & \\
\hline & Pf2 & 0,836 & & & & \\
\hline & Pf3 & 0,888 & & & & \\
\hline & Pf4 & 0,889 & & & & \\
\hline & Pf5 & 0,913 & & & & \\
\hline & Pf6 & 0,852 & & & & \\
\hline & Pf7 & 0,856 & & & & \\
\hline & Pf8 & 0,865 & & & & \\
\hline & Pf9 & 0,910 & & & & \\
\hline \multirow{10}{*}{$\begin{array}{l}\text { Job } \\
\text { Satisfaction }\end{array}$} & JS1 & 0,847 & \multirow{10}{*}{$\begin{array}{l}0,77 \\
5\end{array}$} & \multirow{10}{*}{$\begin{array}{l}\sqrt{\boldsymbol{A V E}}=\mathbf{0 , 8 8 0} \\
\text { Correlation } \\
\text { Coefficient }(\mathrm{r}): \\
0,638,0,744, \\
0,878\end{array}$} & \multirow[t]{10}{*}{0,968} & \multirow[t]{10}{*}{0,972} \\
\hline & JS10 & 0,934 & & & & \\
\hline & JS2 & 0,839 & & & & \\
\hline & JS3 & 0,868 & & & & \\
\hline & JS4 & 0,824 & & & & \\
\hline & JS5 & 0,881 & & & & \\
\hline & JS6 & 0,904 & & & & \\
\hline & JS7 & 0,896 & & & & \\
\hline & JS8 & 0,891 & & & & \\
\hline & JS9 & 0,913 & & & & \\
\hline \multirow{3}{*}{$\begin{array}{l}\text { Work } \\
\text { Environment }\end{array}$} & WE1 & 0,911 & \multirow{3}{*}{$\begin{array}{l}0,83 \\
5\end{array}$} & \multirow{3}{*}{$\begin{array}{l}\sqrt{A V E}=0,914 \\
\text { Correlation }\end{array}$} & \multirow[t]{3}{*}{0,978} & \multirow[t]{3}{*}{0,981} \\
\hline & WE10 & 0,911 & & & & \\
\hline & WE2 & 0,909 & & & & \\
\hline
\end{tabular}




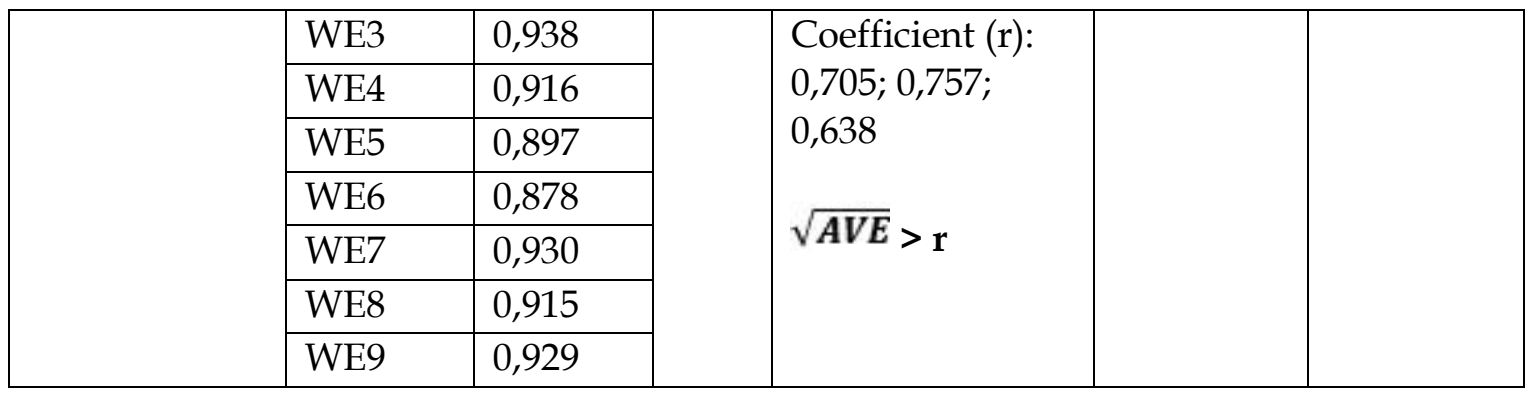

Table 3 shows that all indicators are valid and all constructs are reliable so that the analysis phase can be continued at the inner testing stage of the PLS model.

\section{Testing the Inner Model}

Inner model includes the test of the significance of direct effects, testing the indirect effects, and measurement of the effect of each exogenous variable on endogenous variables. The research hypothesis is a 2-way hypothesis, if Ho is rejected then it is concluded that the exogenous variable significantly influences the endogenous variable if the value of $\mathrm{P}$ value $<0.05$ and $\mathrm{t}$ arithmetic $>1.96$, whereas if not, then Ho is not rejected so it is concluded that the exogenous variable does not affect on endogenous variables.

Table 4. Inner Model Test Results

\begin{tabular}{|c|c|c|c|c|c|}
\hline \multicolumn{6}{|l|}{ Direct Effect } \\
\hline & $\begin{array}{l}\text { Original } \\
\text { Sample } \\
\text { (O) }\end{array}$ & $\begin{array}{l}\text { Sample } \\
\text { Mean } \\
(\mathrm{M})\end{array}$ & $\begin{array}{l}\text { Standard } \\
\text { Deviation }\end{array}$ & $\begin{array}{lr}\text { T } & \text { Statistics } \\
(|\mathrm{O} / \mathrm{STDEV}|)\end{array}$ & \begin{tabular}{|l|}
$\mathbf{P}$ \\
Values
\end{tabular} \\
\hline $\mathrm{OC}->\mathrm{Pf}$ & 0,281 & 0,283 & 0,054 & 5,243 & 0,000 \\
\hline OC -> JS & 0,611 & 0,611 & 0,063 & 9,651 & 0,000 \\
\hline JS -> Pf & 0,599 & 0,595 & 0,052 & 11,508 & 0,000 \\
\hline WE -> Pf & 0,111 & 0,111 & 0,043 & 2,597 & 0,010 \\
\hline WE -> JS & 0,175 & 0,174 & 0,070 & 2,486 & 0,013 \\
\hline \multicolumn{6}{|l|}{ Indirect Effect } \\
\hline & $\begin{array}{l}\text { Original } \\
\text { Sample } \\
\text { (O) }\end{array}$ & $\begin{array}{l}\text { Sample } \\
\text { Mean } \\
\text { (M) }\end{array}$ & $\begin{array}{l}\text { Standard } \\
\text { Deviation }\end{array}$ & $\begin{array}{lr}T & \text { Statistics } \\
(\mid \text { O/STDEV } \mid)\end{array}$ & \begin{tabular}{|l|}
$\mathbf{P}$ \\
Values
\end{tabular} \\
\hline OC -> JS -> Pf & 0,366 & 0,364 & 0,051 & 7,243 & 0,000 \\
\hline WE -> JS -> Pf & 0,105 & 0,103 & 0,042 & 2,504 & 0,013 \\
\hline \multicolumn{6}{|l|}{ Goodness of fit } \\
\hline \multicolumn{6}{|c|}{ SRMR saturated model $=0,077$, SRMR estimated model $=0,077$ (perfect fit model) } \\
\hline
\end{tabular}

Table 4 shows the results of testing the influence and indirect effects of OC and WE variables on Pf mediated by JS. SRMR models both saturated models and estimated models of 0.77 which is still below 0.08 . So it was concluded that the PLS inner model is in the perfect fit criteria so that it is feasible to use to test the hypothesis in this study. Thus, the estimation results of the model to test the hypothesis are illustrated in Figure 4 
Figure 4. Full Estimation Results of PLS Bootstrapping Models

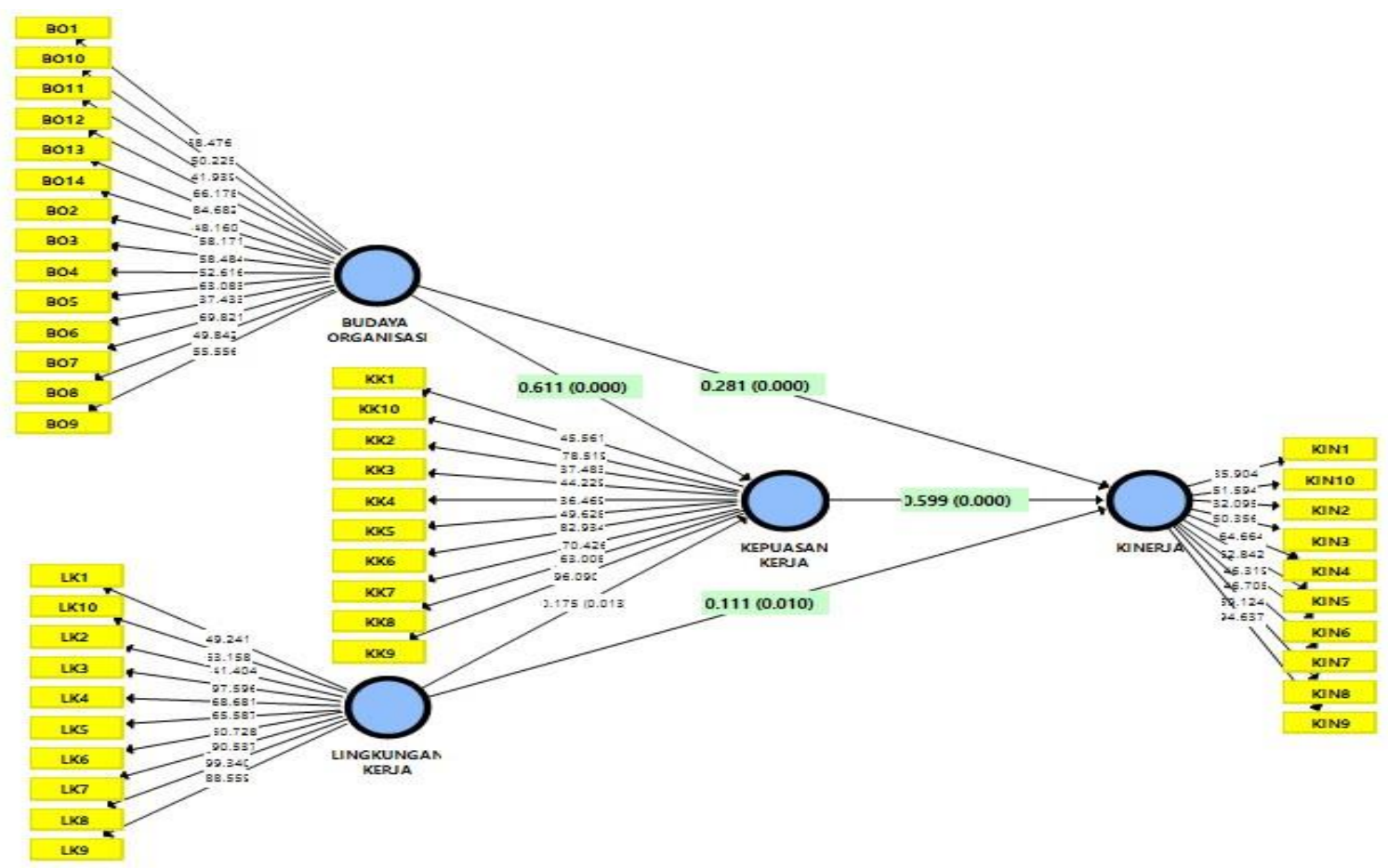

From Figure 4 , it is known that all paths have a $\mathrm{p}$ value $<0.05$. The significance test of direct effect and indirect effect in Figure 5 is more clearly explained in Table 4 and Table 6:

Table 5. Test Results of Direct Effects

\begin{tabular}{|c|c|c|c|c|l|}
\hline & $\begin{array}{c}\text { Original } \\
\text { Sample } \\
(\mathbf{O})\end{array}$ & $\begin{array}{c}\text { Sample } \\
\text { Mean } \\
\mathbf{( M )}\end{array}$ & $\begin{array}{c}\text { Standard } \\
\text { Deviation } \\
\text { (STDEV) }\end{array}$ & $\begin{array}{c}\text { T Statistics } \\
(\mid \text { O/STDEV } \mid)\end{array}$ & $\begin{array}{l}\mathbf{P} \\
\text { Values }\end{array}$ \\
\hline OC-> Pf & 0,281 & 0,283 & 0,054 & 5,243 & 0,000 \\
\hline OC-> JS & 0,611 & 0,611 & 0,063 & 9,651 & 0,000 \\
\hline JS-> Pf & 0,599 & 0,595 & 0,052 & 11,508 & 0,000 \\
\hline WE-> Pf & 0,111 & 0,111 & 0,043 & 2,597 & 0,010 \\
\hline WE-> JS & 0,175 & 0,174 & 0,070 & 2,486 & $\mathbf{0 , 0 1 3}$ \\
\hline
\end{tabular}

Table 6. Test Results for Indirect Effects

\begin{tabular}{|l|c|c|c|c|c|}
\hline & $\begin{array}{c}\text { Original } \\
\text { Sample } \\
(\mathbf{O})\end{array}$ & $\begin{array}{c}\text { Sample } \\
\text { Mean } \\
(\mathbf{M})\end{array}$ & $\begin{array}{c}\text { Standard } \\
\text { Deviation } \\
\text { (STDEV) }\end{array}$ & $\begin{array}{c}\text { T Statistics } \\
(\mid \text { O/STDEV |) }\end{array}$ & $\begin{array}{c}\text { P } \\
\text { Values }\end{array}$ \\
\hline $\begin{array}{l}\text { OC -> JS -> } \\
\text { Pf }\end{array}$ & 0,366 & 0,364 & 0,051 & 7,243 & 0,000 \\
\hline $\begin{array}{l}\text { WE -> JS -> } \\
\text { Pf }\end{array}$ & 0,105 & 0,103 & 0,042 & 2,504 & 0,013 \\
\hline
\end{tabular}

Explanation

OC = Organizational Culture

WE $\quad=$ Work Environment 
Pf $\quad=$ Performance

JS $\quad=$ Job Satisfaction

\section{Hypothesis Testing Results}

Hypothesis testing based on the results of the PLS analysis can be seen in the following Table 7.

Table 7. Summary of Hypothesis Testing Results

\begin{tabular}{|c|l|l|c|}
\hline No & \multicolumn{1}{|c|}{ Hypothesis } & $\begin{array}{c}\text { p value / T } \\
\text { statistics }\end{array}$ & Conclusion \\
\hline $\mathbf{1}$ & OC significant effect on JS (X1 with $\mathrm{Y})$ & $0,000 / 9,651$ & Accept \\
\hline $\mathbf{2}$ & WE significant effect on JS (X2 with $\mathrm{Y})$ & $0,013 / 2,468$ & Accept \\
\hline $\mathbf{3}$ & OC significant effect on Pf (X1 with Z) & $0,000 / 5,423$ & Accept \\
\hline $\mathbf{4}$ & WE significant effect on Pf (X2 with Z) & $0,010 / 2,597$ & Accept \\
\hline $\mathbf{5}$ & JS significant effect on Pf (Y dengan Z) & $0,000 /$ & Accept \\
& & $0,000 / 7,243$ & Accept \\
\hline $\mathbf{6}$ & $\begin{array}{l}\text { OC significant effect on Pf with } \\
\text { mediated by JS (X1 with Z with } \mathrm{Y})\end{array}$ & $0,013 / 2,504$ & Accept \\
\hline $\mathbf{7}$ & $\begin{array}{l}\text { WE significant effect on Pf with } \\
\text { mediated by JS (X2 with Z with } \mathrm{Y})\end{array}$ & \\
\hline
\end{tabular}

Because $\mathrm{p}$ value $<0.05, \mathrm{~T}$ statistic $>1.96$ and positive path coefficient, it can be concluded that the overall effect is positive and significant.

The discussion of the study, is described in Table 8 .

Table 8. Research Discussion

\begin{tabular}{|c|l|c|c|}
\hline No. & \multicolumn{1}{|c|}{ Variable } & $\begin{array}{c}\text { Variables have a } \\
\text { positive and } \\
\text { significant } \\
\text { relationship }\end{array}$ & $\begin{array}{c}\text { Path Coefficient } \\
\text { Value }\end{array}$ \\
\hline 1. & OC » JS & $\checkmark$ & 0,611 \\
\hline 2. & WE $~ J S$ & $\checkmark$ & 0,175 \\
\hline 3. & OC Pf & $\checkmark$ & 0,611 \\
\hline 4. & WE Pf & $\checkmark$ & 0,111 \\
\hline 5. & JS Pf & $\checkmark$ & 0,599 \\
\hline 6. & $\begin{array}{l}\text { OC with Pf with mediated by } \\
\text { JS }\end{array}$ & Significant & 0,366 \\
\hline 7. & $\begin{array}{l}\text { WE with Pf with mediated by } \\
\text { JS }\end{array}$ & Significant & 0,105 \\
\hline
\end{tabular}

The results stated OC contributed $61.1 \%$ to the JS, WE contributed $17.5 \%$ to the JS, OC contributed $61.1 \%$ to Pf, WE to Pf contributed $11.1 \%$ of, JS contributed to Pf about $59.9 \%$, so the relationship of all research variables is concluded to be positive and significant because the whole has an influence. Then, there is the influence of OC with Pf mediated by JS with Pf which has a path coefficient value of 0.366 , and there is an influence of WE with Pf mediated by JS which has a path coefficient value of 0.10 .

This finding showed that organizational culture and work environment with job satisfaction are positively and significantly related, organizational culture and work environment with performance are positively and significantly related, job satisfaction 
with performance is positively and significantly related, there is a relationship between the influence of organizational culture and performance with mediated by job satisfaction and there is a relationship between the influence of the work environment with performance mediated by job satisfaction. Organizational commitment and job satisfaction were high performance too in increasing employees in different organization (Fabi, Lacoursière, \& Raymond, 2015). Other studied also revealed that the significant joint mediating effects of engagement and trust on professionals' job satisfaction, when supportive organizational culture and excellent leader performance were achieved (Meng \& Berger, 2019). It a line with Al-Sada (2017) who reported that there were Significant positive relationships between supportive culture and job satisfaction; supportive culture and organizational commitment; participativesupportive leadership and job satisfaction; directive leadership and job satisfaction; job satisfaction and work motivation; job satisfaction and organizational commitment. While, current ideal culture incongruence were negatively associated with job satisfaction (Jung, 2018).

\section{CONCLUSIONS}

The result concluded that the work environment in the seskoal has been good. Organizational Culture in the council is good criteria. The Job Satisfaction of most soldiers has been high. However, in terms of supervision of the performance of soldiers, the average value is still low. The soldier has a good performance but still needs to improve his performance, namely by trying to always be able to complete the task without the help of other colleagues, not playing Handphone, and can reduce errors while working.

\section{ACKNOWLEDGEMENTS}

The authors sincere their appreciation to the Seskoal Soldiers that consisting of 118 Bintara people, and 92 Private Officers to give permission to conduct our research. And everyone thanks who has contribute their thought, time and energy to help finish their research.

\section{AUTHOR CONTRIBUTION STATEMENTS}

The authors had participated in the research and approved the final version of the manuscript.

\section{REFERENCES}

Al-Sada, M., Al-Esmael, B., \& Faisal, M. N. (2017). Influence of organizational culture and leadership style on employee satisfaction, commitment and motivation in the educational sector in Qatar. EuroMed Journal of Business. https://doi.org/10.1108/EMJB-02-2016-0003

Alizadeh, Z., Darvishi, S., Nazari, K., \& Emami, M. (2012). Antecedents and Consequences of Organisational Citizenship Behaviour (OCB). Interdisciplinary Journal Of Contemporary Research in Business, 9. Google Scholar

Asiedu, E. (2015). Supportive Organizational Culture and Employee Job Satisfaction: A Critical Source of Competitive Advantage. A Case Study in a Selected Banking Company in Oxford, a City in the United Kingdom. International Journal of $\begin{array}{llll}\text { Economics } & \mathcal{E} & \text { Management }\end{array}$ https://doi.org/10.3126/ijssm.v2i3.12551 
Belias, D. (2015). Organizational Culture and Job Satisfaction of Greek Banking Institutions. Procedia - Social and Behavioral Sciences. Elsevier B.V., 175, 314-323. Google Scholar

Chaudhry, N. (2017). Impact Of Working Environment And Training \& Development On Organization Performance Through Mediating Role Of Employee Engagement And Job Satisfaction. European Journal of Training and Development Studies, 33-48. Google Scholar

Che, R. R., Kumar, N., \& Pak, O. G. (2019). The Effect of Organizational Learning On Organizational Commitment, Job Satisfaction And Work Performance. Journal of Applied Business Research Vol.25. No.6 (Nov/Dec), 55-65. https://doi.org/10.19030/jabr.v25i6.995

Colquitt, L., \& Wesson. (2013). Organizational Behavior, Improving Performance and Commitment in Workplace. Third Edit. New York: McGraw-Hill Companies, Inc. Google Scholar

Fabi, B., Lacoursière, R., \& Raymond, L. (2015). Impact of high-performance work systems on job satisfaction, organizational commitment, and intention to quit in Canadian organizations. International Journal of Manpower. https:/ / doi.org/10.1108/IJM-01-2014-0005

Hanafi, B. D., \& Yohana, C. (2017). Pengaruh Motivasi, Dan Lingkungan Kerja, Terhadap Kinerja Karyawan, Dengan Kepuasan Kerja Sebagai Variabel Mediasi Pada PT BNI Lifeinsurance. Jurnal Pendidikan Ekonomi dan Bisnis (JPEB), 73-89. https://doi.org/10.21009/JPEB.005.1.6

Hardiyono, Hamid, N., \& Mardiana, R. (2017). The Effect of Work Environment and Organizational Culture on Employees Performance through Job Satisfaction as Intervening Variable at State Electricity Company (PLN) of South Makasar Area. Advances in Economics, Business and Management Research, 40:86-96. https://doi.org/10.2991/icame-17.2017.7

Indrasari, M. (2017). The Effect Of Organizational Culture, Environmental Work, Leadership Style On The Job Satisfaction And Its Impact On The Performance Of Teaching In State Community Academy Bojonegoro. Sinergi: Jurnal Ilmiah Ilmu Manajemen, 58-73. Google Scholar

Jayaweera, T. (2015). Impact of Work Environmental Factors on Job Performance, Mediating Role of Work Motivation: A Study of Hotel Sector In. International Journal of Information, Business and Management, 10(3):271-78. Google Scholar

Jung, C. S. (2018). Current-ideal culture incongruence, hierarchical position, and job satisfaction in government agencies. International Public Management Journal, 21(3), 432-460. https:/ / doi.org/10.1080/10967494.2016.1276492

Khuzaeni, Idrus, M., Djumahir, \& Solimun. (2013). The Influence of Work Culture, Work Stress to the Job Satisfaction and Employees Performance in the State Treasury Service Office in Jakarta, Indonesia. IOSR Journal of Business and Management (IOSR-JBM) e-ISSN: 2278-487X, p-ISSN: 2319-7668, 9(2):49- 54. Google Scholar

Meng, J., \& Berger, B. K. (2019). The impact of organizational culture and leadership performance on PR professionals' job satisfaction: Testing the joint mediating effects of engagement and trust. Public Relations Review, 45(1), 64-75. https://doi.org/10.1016/j.pubrev.2018.11.002

Naibaho, H., Firmanto, A., \& Sugiarto, V. (2010). Pengaruh Lingkungan Kampus terhadap Motivasi Belajar Mahasiswa (Studi Kasus Universitas Pelita Harapan 
Surabaya). Jurnal Manajemen Pemasaran, Vol 5, No 1, April , 22-26. https://doi.org/10.9744/pemasaran.5.1.22-26

Pawirosumarto, S., Sarjana, K. P., \& Gunawan, R. (2017). The Effect of Work Environment, Leadhershipstyle, and Organizational Culture Towards Job Satisfaction and Its Implication Towards Employee Performance in Parador Hotels and Resorts, Indonesia. International Journal of Law and Mangement Vol.59, 6. https:/ / doi.org/10.1108/IJLMA-10-2016-0085

Pitaloka, E., \& Sofia, I. P. (2014). The Affect Of Work Environment, Job Satisfaction, Organization Commitment On Ocb Of Internal Auditors. International Journal of Business, Economics and Law, 5. Google Scholar

Salunke, G. (2015). Work Environment and Its Effect on Job Satisfaction in Cooperative Sugar Factories in Maharashtra, India. Abhinav International Monthly Refereed Journal of Research in Management \& Technology Vol 4, 22. Google Scholar

Steven Set Xaverius Tumbelaka, T. A. (2016). Pengaruh Budaya Organisasi Terhadap Kepuasan Kerja, Komitmen Organisasional Dan Intention To Leave (Studi pada Karyawan PT.Bitung Mina Utama). Jurnal Bisnis dan Manajemen Vol. 3 No.1, 94108. Google Scholar

Sugiono. (2018). Metode Penelitian Bisnis. Bandung: edited by S. Suryandri. Google Scholar

Syahrum, Andi, Brahmasari, I. A., \& Nugroho, R. (2016). Effect of Competence, Organizational Culture and Climate of Organization to the Organizational Commitment, Job Satisfaction and the Performance of Employees in the Scope of Makassar City Government. International Journal of Busines and Management Invention, 5(4):52-64. Google Scholar 